\title{
MULHERES CATADORAS DE MATERIAIS RECICLÁVEIS DE SANTANA DO LIVRAMENTO/RS: TRAJETÓRIAS DE LUTA EM BUSCA DA EMANCIPAÇÃO SOCIAL
}

\author{
Nadia Scariot ${ }^{1}$ \\ Cassiane da Costa ${ }^{2}$ \\ Universidade Estadual do Rio Grande do Sul
}

Recibido 15/04/2019 Aceptado 15/05/2019

Este estudo buscou conhecer a trajetória de vida de mulheres catadoras de materiais recicláveis da Associação de Catadores Novo Horizonte, em Santana do Livramento-RS. Direcionamos o olhar às dificuldades enfrentadas, aos sonhos e à ausência de sonhos, à forma como se veem e se organizam, bem como às perspectivas que têm para o futuro na associação. Recorremos ao Método de História de Vida, realizando cinco entrevistas, com auxílio de um roteiro de questões semiestruturadas. Entendemos que esta pesquisa contribui para a afirmação das vivências das mulheres pesquisadas que, ao ouvirem suas próprias vozes, tiveram a possibilidade de valorizarem suas trajetórias, percebendo-se capazes de experienciarem novos caminhos, como o associativo, em busca da emancipação social.

Este estudio ha buscado conocer la trayectoria de vida de las mujeres recolectoras de materiales reciclables de la "Associação de Catadores Novo Horizonte", en Santana do LivramentoRS. Dirigimos la mirada a las dificultades enfrentadas, los sueños y la ausencia de sueños, a la forma como se ven y se organizan, así como las perspectivas que tienen para el futuro en la asociación. Hemos recurrido al Método de Historias de vida, realizando cinco entrevistas, con el auxilio de un guión de cuestiones semi-estructuradas. Entendemos que esta investigación ha contribuido para la afirmación de las experiencias vividas por las mujeres investigadas que, al escuchar sus propias voces, han tenido la posibilidad de valorar sus trayectorias, percibiéndose capaces de experimentar nuevos caminos, como el asociativo, en búsqueda de la emancipación social.

DOI

https://doi.org/10.15366/didacticas2019.20.005

1. Correo electrónico: nadia.scariot@gmail.com

2. Correo electrónico: cassicostafx@gmail.com
PALABRAS CLAVE

Associação de Catadores Novo Horizonte; Catadoras de materiais recicláveis; Emancipação social; Histórias de vida.

\section{KEYWORDS}

Asociación de Recolectoras de residuos Novo Horizonte; Recolectoras de materiales reciclables; Emancipación social; Historias de vida. 


\section{INTRODUČ̃O}

Nos dias atuais, um paradoxo se faz notar: de um lado a emergência de uma sociedade de consumo que transforma tudo em mercadoria e a reifica, com a promessa ilusória de uma felicidade geral para ser vivida aqui e agora. De outro, o aumento da situação calamitosa de pobreza e exclusão social que transforma milhares de pessoas em consumidores falhos, refugos humanos, conforme o entendimento de Bauman (2005).

Nesta última perspectiva é que se encontram os catadores e as catadoras de materiais recicláveis, sobrevivendo do descarte de mercadorias que, devido a uma curta vida útil, logo viraram resíduos. Estes (as) trabalhadores (as), na esperança de uma vida melhor, procuram no modo associativo um espaço de organização coletiva que lhes garanta, além da sobrevivência imediata, melhores condições de vida. Dos sujeitos que sobrevivem desta atividade, as mulheres aparecem em maior número - $70 \%^{1}$ e dentre os motivos estaria a possibilidade de conciliarem as atividades da catação com o cuidado do lar e da família. A predominância de mulheres, de acordo com Hillenkamp; Guérin; Verschuur, 2017, p. 43), é percebida "em várias iniciativas de economia solidária, tanto em países do hemisfério norte quanto do sul". Na Associação de Catadores Novo Horizonte ${ }^{2}$, de Santana do Livramento-RS, também se verifica um maior número de mulheres trabalhadoras: dos 20 associados, 14 são mulheres e 06 são homens, fato que nos direcionou para um recorte de gênero, enfocando as vivências e o trabalho das mulheres catadoras.

Dessa forma, neste estudo, buscamos conhecer quem são as catadoras de materiais recicláveis que participam da Associação de Catadores Novo Horizonte e direcionamos o olhar às dificuldades enfrentadas, aos sonhos e à ausência de sonhos, à forma como se veem e se organizam, bem como às perspectivas que têm para o futuro na associação. Devido ao fato de a Associação encontrar-se ainda em processo de estruturação física e identitária, torna-se difícil avaliar a atuação das associadas como grupo ativo. Assim, além dos aspectos objetivos, relativos ao trabalho associativo, buscamos compreender também os subjetivos, relacionados às suas vivências.

Metodologicamente, fizemos uso do Método de História de Vida (Amado, 2014; Josso, 2004) e realizamos entrevistas com apoio de um roteiro de questões semiestruturadas, nas residências dos sujeitos de pesquisa. A presença da professora orientadora e de um membro da Incubadora de Empreendimentos Econômicos Solidários Fronteira da Paz, que já conheciam as entrevistadas, deu ares de familiaridade às conversas, que poderiam não fluir da mesma forma, uma vez que eu lhes era desconhecida, até então. Ao todo, foram em-

\footnotetext{
${ }^{1}$ Conforme estimativa do Movimento Nacional dos Catadores de Materiais Recicláveis (MNCR), apresentada em 2014. Disponível em: [Enlace]Acesso em: 23 nov. 2018.

${ }^{2}$ A Associação Novo Horizonte foi fundada em 2014, por meio do Projeto Minuano, e a partir de 2016 passou a ser incubada pela Incubadora de Economia Solidária Fronteira da Paz, inicialmente situada na Universidade Estadual do Rio Grande do Sul (UERGS), e atualmente na Universidade Federal do Pampa (Unipampa), funcionando na forma de parceria entre essas instituições de ensino e o Instituto Federal de Educação, Ciência e Tecnologia Sul-rio-grandense (IFSul).
} 
trevistadas ${ }^{3}$ cinco mulheres associadas e a escolha destas ocorreu em função de serem as mais atuantes na associação. A idade das entrevistadas varia de 27 a 60 anos e todas residem na parte noroeste da cidade, mais precisamente os Bairros Prado, Chão batido e Parque das Águas. As entrevistas gravadas foram transcritas. Cada entrevistada assinou o Termo de Consentimento Livre e Esclarecido. À exceção de uma entrevistada ${ }^{4}$, o nome de todas as outras foram mantidos, pois quando perguntadas se gostariam de ter suas identidades divulgadas ou preservadas, manifestaram interesse em contar sua história, para ser publicada em um livro.

Além do conceito de Histórias de Vida, como pressuposto teórico metodológico, também foi utilizado o conceito de Economia Solidária (Singer, 2002), Educação Popular (Freire, 2002;2011) e Emancipação Social(Sousa Santos, 2000; 2006; 2007) para permearem a pesquisa. Este último conceito juntamente com as histórias de vida são os aportes condutores do estudo, uma vez que, imbricados, contribuem para a afirmação das vivências das mulheres pesquisadas, que ao se falarem, ouvirem suas próprias vozes, tiveram a possibilidade de valorizarem suas trajetórias já experimentadas, de perceberem-se como sujeitos sociais, não apenas como excluídas, capazes de conhecer novos caminhos, como, por exemplo, o associativismo.

Ao ingressarem num empreendimento associativo, novas formas de relação se fazem necessárias: não mais apenas competitiva, do só pensar em si, da busca da sobrevivência imediata; mas da cooperação e solidariedade entre os membros, de alguém que agora é responsável pela gestão do empreendimento, fato que requer, entre outras coisas, poder de decisão, portanto um consenso coletivo. Compreender-se como sujeito valorizado pelo trabalho que realiza, pelos saberes que desenvolve na sua atividade, capaz de atuar coletivamente, é ter autonomia e é, em certa medida, emancipar-se socialmente.

Para uma melhor compreensão do estudo, dividimo-lo em quatro partes. Na primeira, trazemos a apresentação e introdução do assunto, na qual informamos nossas motivações e objetivos e como foi conduzido o trabalho. Na segunda, apresentamos os aportes teóricos metodológicos utilizados. Na terceira, para analisar e problematizar as histórias de vida, classificamos as histórias de vida das cinco entrevistadas por temas: a) fases de vida e de luta, b) representação social da mulher catadora, c) organização do trabalho, sonhos, d) inserção na associação e perspectivas para a associação. Na quarta e última parte, apresentamos as conclusões, ou seja, o que pode ser depreendido de tudo isto.

\footnotetext{
${ }^{3}$ Realizadas de 03/09/2018 a 02/10/2018.

${ }^{4}$ Optou-se por um nome fictício pois a entrevistada recebe o seguro Auxílio-doença, pelo Instituto Nacional de Seguridade Social (INSS).
} 


\section{APORTES TEÓRICOS E METODOLÓGICOS DA PESQUISA}

\section{Contribuições da Economia Solidária e da Educação Popular}

Embora tenha sido fundada no ano de 2014, a Associação de Catadores Novo Horizonte, de Santana do livramento-RS, ainda não possui efetivamente estrutura física adequada para o desenvolvimento do trabalho coletivo na reciclagem. Faltam-lhe coisas básicas como, por exemplo, galpão e equipamentos (balança, prensa etc.), fato que tem dificultado, além do trabalho prático, que os associados se percebam como grupo. Neste ano de 2018, a associação recebeu, por doação do Departamento Nacional de Infraestrutura de Transporte (DNIT), um espaço para servir de galpão, que está em processo de licitação para compra de equipamentos e melhorias da estrutura física. A referida associação, pelo fato de estar sendo incubada, recebe incentivo para atuar na perspectiva da economia solidária, que incentiva a cooperação, a autogestão, implicando na participação efetiva dos associados e associadas em todas as decisões do empreendimento.

O horizonte da economia solidária, conforme Hillenkamp; Guérin; Verschuur (2017, p. 47), pode ser descrito como "uma inversão de valores que requer novas concepções da riqueza”. Para Singer (2002, p. 83) a Economia Solidária é vista como uma alternativa de trabalho e renda para muitas pessoas que não conseguem inserir-se no mercado formal de trabalho. Nesta perspectiva, os (as) trabalhadores (as) de um empreendimento econômico solidário, além de terem trabalho e renda, tornam-se proprietários (as) e, por conseguinte, donos (as) de seu capital, assumindo também o poder nas decisões. No entanto, o autor entende que para que ela vire processo, além dos aspectos econômicos, devem ser trabalhados também os aspectos inerentes à cooperação, como a solidariedade e a participação.

O enfoque da Educação Popular e da Economia Solidária na pesquisa remete a uma abordagem crítica da realidade social que permite, além de compreender a realidade vivida pelos sujeitos pesquisados, a possibilidade de transformação dessa realidade pelos próprios sujeitos envolvidos no processo. A educação popular, como educação libertária, problematizadora, oferece aos sujeitos a possibilidade de se perceberem como efeito de um sistema que os explora, marginaliza e os torna descartável quando não conseguem se integrar a ele. Entretanto, ao mesmo tempo em que discute as mazelas sociais, ao invés de conformarse com elas, propõe e cria novas alternativas, a partir de novos valores de solidariedade e cooperação entre as pessoas. Neste ponto é importante lembrar que o trabalho de incubação já desenvolve atividades de formação e de conscientização, com os catadores e as catadoras.

No que tange à Educação Popular, a mesma possibilita um processo formativo, em que catadores e catadoras podem desenvolver suas aprendizagens partindo de situações cotidianas concretas, que os levem a refletir sobre suas experiências vividas. Freire (2011, p. 44) salienta que "quanto mais as massas populares desvelam a realidade (...) tanto mais se 'inserem' nela criticamente”. 
Para Singer (2002, p. 83), a economia solidária é mais que um modo de produção, ela é também um novo modo de vida, de relações, pois está embasada na solidariedade entre as pessoas, no estabelecimento de laços de confiança e na participação dos trabalhadores.

\section{Emancipação Social}

O conceito de emancipação de Boaventura de Sousa Santos ${ }^{5}$ pretende consolidar um paradigma que promova a emancipação social, desconstruindo as verdades constituídas pela ciência, pois "todo conhecimento científico é socialmente construído, o seu rigor tem limites inultrapassáveis e a sua objetividade não implica na sua neutralidade" (Sousa Santos, 2006, p. 9). O autor entende que a racionalidade ocidental criou uma razão que ele chama de indolente - que contribuiu para as monoculturas de saber, de tempo, de naturalização das diferenças, das escalas dominantes e do produtivismo capitalista, as quais foram responsáveis por produzir na sociedade a imagem do ignorante, do residual, do inferior, do local e do improdutivo (adjetivos geralmente atribuídos aos (às) catadores (as)). Na contramão dessas monoculturas, propõe uma ecologia dos saberes (entre eles os populares), das temporalidades, dos reconhecimentos, das trans-escalas e da produtividade (que valoriza, por exemplo, as iniciativas de economia solidária). (Ibid., 2007, p. 9).

Nesta mesma linha de raciocínio, na obra Pedagogia da Autonomia, Freire (2002, p. 113) assevera que "o avanço da ciência e/ou da tecnologia pode legitimar uma "ordem" desordeira em que só as minorias do poder esbanjam e gozam enquanto às maiorias (...) [dizem, por medo] que sua fome é uma fatalidade do fim do século”. As conclusões a que chegaram estes dois autores permitem-nos compreender as dificuldades dos excluídos valorizarem seus saberes, suas experiências, por não serem científicas, objetivas, mensuráveis.

Retomando Sousa Santos (2007, p. 41) em sua proposta de uma "Epistemologia do Sul", o autor provoca para uma nova forma de perceber outras racionalidades, as locais, que permitam "observar a riqueza e não desperdiçar as experiências sociais produzidas ao redor do mundo, sobretudo no Sul, lócus que historicamente sofre com processos de exclusão e discriminação". Além disso, considera que é necessário "defender a igualdade sempre que a diferença gerar inferioridade e defender a diferença sempre que igualdade implicar descaracterização" (Sousa Santos; Nunes, 2004, p. 47-48). O multiculturalismo, conforme Sousa Santos (2000, p. 27), através dos procedimentos da sociologia das emergências e do trabalho de tradução, torna "as diferentes lutas mutuamente inteligíveis permitindo aos “atores coletivos 'conversarem' sobre as opressões a que resistem e as aspirações que os animam". E finaliza: "Necessitamos de uma teoria sobre a impossibilidade de uma teoria geral. Estamos de acordo que ninguém tem a receita, ninguém tem a teoria”. (Ibid., p. 39).

\footnotetext{
${ }^{5}$ Pesquisador português, sociólogo, um dos idealizadores do Fórum Social Mundial e do Projeto Reinventar a Emancipação Social.
} 
É nessa perspectiva que se compreende a contribuição das histórias de vida, no sentido de que, ao contarem sobre suas vivências, as entrevistadas vão se dando conta da sua historicidade, do lugar social que se encontram e que foram colocadas. Obviamente, este estranhamento exige orientação teórico-crítica, que deve ser proporcionado, mediante trabalhos de formação em educação popular, pelas assessorias das incubadoras de economia solidária.

\section{A contribuição metodológica das Histórias de Vida}

Visando o desenvolvimento territorial do Pampa, a partir dos atores locais, várias pesquisas vêm sendo realizadas no intento de resgatar/afirmar as potencialidades desta região. Nesse sentido, é importante valorizar, além dos aspectos objetivos também os subjetivos, por contribuem para a compreensão de como os sujeitos representam os acontecimentos e os fenômenos sociais, históricos e culturais, com a finalidade de refletirem sobre suas próprias vivências.

Howard Becker (1999, p. 111) destaca que "por causa da 'própria história' de seus atores, a história de vida é uma mensagem viva e vibrante de quem vem de 'lá', que nos contam o que significa ser um tipo de pessoa que nunca encontramos face a face. Para Amado (2014), p. 170, ela "representa também uma estratégia de formação, em que o que se aprendeu e experienciou na vida (...), revela-se como um processo dinamizador de novos percursos e metas de vida". E, ainda, de acordo com Josso (2004, p. 61) "três níveis de análise em profundidade permitem caracterizar as grandes etapas do trabalho biográfico ao longo do processo: evidencia do processo de formação, evidência do processo de conhecimento e evidência dos processos de aprendizagem”.

Sobre estas últimas duas últimas afirmações - Amado e Josso - é que compreendemos a importância da utilização das histórias de vida no presente trabalho, uma vez que o mesmo está vinculado ao Projeto Incubação de Empreendimentos Econômicos Solidários na Fronteira da Paz - Santana do Livramento - RS. Sendo assim, este estudo será utilizado nas formações das catadoras. Ao discorrerem sobre suas vidas, elas passam a se conhecerem melhor, perceberem-se como sujeitos, como mulheres empoderadas, com conhecimentos de si, que poderá lhes permitir, conforme Amado (2014), novos percursos e metas de vida.

\section{TRAJETÓRIAS DE LUTAS DAS CATADORAS}

Nas páginas que seguem, apresentaremos um breve resumo das histórias de vida das mulheres catadoras entrevistadas. O material coletado permite muitas análises e problematizações, que neste espaço não foi possível aprofundar, devido ao limite de páginas exigido em um artigo. Entretanto, consideramos que as falas elencadas são bastante esclarecedoras, "falam por si só" e, dessa forma, elegeram-se alguns temas para serem apresentados 
nesta secção, tais como: fases da vida/lutas, representação do ser mulher catadora, organização do trabalho, sonhos, inserção e perspectivas na e para a associação. Além disso, cabe ressaltar que as falas das entrevistadas foram transcritas em sua íntegra e, nesse sentido, as correções segundo a norma culta da Língua Portuguesa não são relevantes para o estudo.

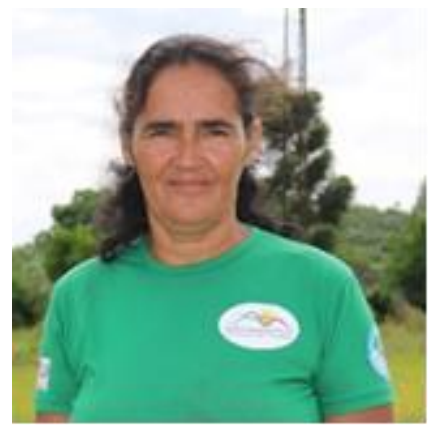

Figura 1. Catadora Sara Barrios Soarez. Fonte: Acervo Incubadora de ES Fronteira da Paz. UNIPAMPA.

\section{Sara Barrios Soarez}

“(...) eu tô pro que der e vier, se tiver que passar fome pela associação, eu passo".

Sara Barrios Soarez, atual presidente da Associação, nasceu em Santana do Livramento, é moradora do bairro Chão Batido e tem 45 anos. Ela estudou até o sexto ano incompleto e, recentemente, voltou a frequentar o EJA ${ }^{6}$. Casou-se aos 14 anos, mãe de 10 filhos que criou sozinha, pois seu exmarido, "quando ele via a coisa feia ele ia [embora], aí eu aprendi a trabalhar". A necessidade de sustentar seus filhos, devido ao abandono sofrido pelo companheiro e pai das crianças, foi o principal motivo que a levou a trabalhar na ca-

tação de material reciclável.

Desde então, Sara continua coletando (garrafas pet, cobre, alumínio, plástico, cartão etc.) e vendendo, geralmente, para as empresas de reciclagem Águia ou Alama. Perguntada se mantem um controle sobre o que coleta e o que vende, informou que apenas entrega e confia no que lhe dizem e pagam os compradores. Sobre a rotina de trabalho na catação, diz ter se acostumado e tomado gosto por este trabalho, pois "o dia que não saio fico bem louquinha. Lixeiro é um serviço que todo dia tem. É pouco, mas tem!”.

Sara coleta com uma carroça puxada pela sua égua Cigana - "minha relíquia, meu ganha-pão"7 - todos os dias, mas, principalmente, nas segundas, quartas e sextas-feiras, que são os "dias de lixo", como ela diz. Concilia o trabalho da catação com os cuidados com os (as) filhos (as) e os trabalhos da casa. Dois filhos e uma filha, que são crianças, ficam o dia todo na escolinha, enquanto ela trabalha. Além dos pequenos, também dedica bastante tempo à luta pela recuperação de um filho de 14 anos viciado em crack. Conforme Sara, ela não quer reviver a imensa dor que passou quando perdeu um filho jovem para as drogas.

\footnotetext{
${ }^{6}$ Educação de Jovens e Adultos. Modalidade de estudos para jovens e adultos que não deram continuidade em seus estudos e para aqueles que não tiveram o acesso ao Ensino Fundamental e/ou Médio na idade apropriada. Disponível em: [Enlace] Acesso em: 18 nov. 2018.

${ }^{7}$ Como Sara carinhosamente chama sua égua.
} 
Ela realiza a coleta, geralmente, nos bairros Julieta e Prado, e pessoas conhecidas guardam material para lhe entregar. Necessita vender, diariamente, o que coleta, pois não tem onde estocar o que recolhe. Com a venda da coleta, recebe, diariamente, em média, cerca de R\$50,00. Sua renda é complementada pelo recebimento da Bolsa Família, que recebe há quase cinco anos. Ela diz não ter vergonha de catar, que até gosta quando lhe chamam de lixeira e que não se ofende por isso. Quanto à mudança de nomenclatura, de lixeiro para catador de material reciclável, perguntada no sentido de perceber se isso lhe traria uma maior valorização social, Sara diz que o que mudou foi "só a palavra, porque é a mesma coisa. (...) antes quando ajuntava dizia lixo, agora que é reciclagem, e não mudou nada. (...). Só a palavra é bonita, né. Ficou mais bonito”, afirma.

Sua entrada para a Associação Nova Horizonte, em 2016, foi a convite do Professor Altacir $^{8}$, que a encontrou em uma tarde na rua, quando coletava, e também por ser este uma pessoa em quem deposita muita confiança: "acho que o entusiasmo, o apoio do professor, que ele apoia a gente, né. Que a gente pode contar com ele (...). Aí ele me falou e eu me interessei. (...)". Como presidente da associação, Sara está disposta a lutar pelo seu fortalecimento.

A associação, em seu ver, é como uma família, que necessita de diálogo e não pode ser algo imposto. Tanto pelo trabalho no galpão, como pela futura possibilidade de assumirem a coleta seletiva. Entende que é necessário ter regras, horários e que quem não cumprir "tem que dar suspensão de dois dias, porque tem fila de espera". Sobre uma experiência de trabalho coletiva que tiveram anteriormente ${ }^{9}$, entende que esta foi pouco exitosa, devido a vários fatores como, falta de cumprimento dos horários e regras estabelecidas, mas, principalmente, pelo autoritarismo de um colega.

Uma das coisas mais importantes que Sara destaca em participar da associação são as viagens, pois considera que sempre aprende muitas coisas, além de suas participações nas reuniões, na universidade: "O professor [Altacir] me liga ou o Edenilson, pra uma reunião, eu fico mais que faceira porque lembraram de mim".

Quando inquirida sobre o que representa para ela ser mulher e catadora, reflete: "Acho que uma mulher catadora é olhar o que vem pela frente. Essa mulher que luta, não, não sei. É uma guerreira, que não se abaixa por pouca coisa”.

Acredita que a associação só se viabilizou pelo apoio da Incubadora que, do contrário, não teriam se reunido, pois quando perguntada sobre o que vê para o futuro da Associação, comenta: "Eu tô vendo um futuro bem grande pra nós catadores, mas bem grande mesmo,

\footnotetext{
8 Altacir Bunde, professor da Unipampa, atual coordenador da Incubadora Fronteira da Paz.

${ }^{9}$ Em novembro de 2017 participaram de dois mutirões: IV SIEPE (salão Internacional de ensino, Pesquisa e Extensão, realizado pela Unipampa) e uma experiência de coleta seletiva, realizada no centro da cidade e nos bairros Prado e Parque das Águas. Em 2018, trabalham no recolhimento de materiais em um show, realizado na Chácara da Prefeitura Municipal de Santana do Livramento. A referência a estas experiências de trabalho coletivo aparecerá em todas as entrevistas.
} 
e com o professor junto(...)". Depois esclarece: "No início, tudo é dificultoso, né? Mas eu tô pro que der e vier, se tiver que passar fome pela associação, eu passo". Sobre seus sonhos, mencionou que nunca os teve, mas seu desejo é ter uma casa em condições de viver ali dentro e ver seus filhos bem.

A história de Sara nos mostra uma mulher batalhadora e decidida, que diante das dificuldades que a vida lhe impôs, lançou mão do trabalho na catação para sustentar a família. Como presidente da Novo Horizonte, está disposta a enfrentar os maiores sacrifícios, se necessário, pelo fortalecimento da associação.

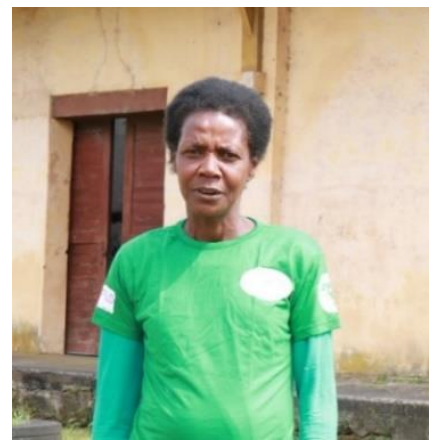

Figura 2. Olívia Pereira. Fonte: Acervo Incubadora de ES Fronteira da Paz - UNIPAMPA.

\section{Olívia Pereira}

"Eu gosto de separar, de limpar, de arrumar, essas coisas assim de... reciclagem".

Olívia, 54 anos, moradora do bairro Prado, em Livramento, é natural de São José do Norte/RS. Aos sete anos, quando seus pais faleceram, foi morar em Rio Grande, na casa da irmã. Lá, dos 13 aos 19 anos, trabalhou numa fábrica de peixe, de onde saiu para acompanhar o marido a Santana do Livramento, "que veio fugido de lá, porque aprontou", conforme relatou a entrevistada. Mãe de 10 filhos, seis vivos e quatro já falecidos.

Em seguida que chegou a Livramento foi morar em Rivera, Uruguai, e, tempos depois, voltou novamente para Livramento, porque teve sua casa queimada, em um incêndio provocado por uma vela acesa, pois não tinham energia elétrica. Neste incêndio perdeu uma filha, de três anos.

Os primeiros trabalhos que realizou em Livramento foi de faxineira, porém, com o nascimento dos filhos, ficou difícil conciliar os horários, uma vez ficava sobrecarregada de atividades, pois seu marido, que trabalhava em uma Igreja de Rivera, viajava constantemente. $\mathrm{O}$ fato de ser analfabeta ${ }^{10}$ também lhe impediu de continuar nas faxinas, porque não podia ler bilhetes e receitas que as patroas lhe pediam, nem anotar recados telefônicos. Dessa forma, na catação, podendo levar as crianças consigo, encontrou a possibilidade de conciliar trabalho e renda, juntando ferro e garrafa que vendia para a empresa Águia ou Poliano ${ }^{11}$.

Mara não soube precisar exatamente quantos anos faz que está nessa atividade, só disse que desde que seus filhos eram pequenos. Até hoje, somente ela e as filhas estão na catação, seu esposo está aposentado e não trabalha. Contou que a situação foi melhorando quando

\footnotetext{
${ }^{10}$ Nunca frequentou a escola, pois seu pai lhe dizia que não precisava estudar, tinha que trabalhar. Para assinar seu nome necessita copiá-lo da carteira de identidade ou carimbar com o dedo.

${ }^{11}$ Empresas de reciclagem.
} 
uma assistente social do município conseguiu o benefício de um salário mínimo para um de seus filhos que tem problemas mentais. Atualmente, diz que não cata todos os dias "por causa que como agora eu pego um dinheiro de uma assistência social, né?! Antes eu ia [catar] todos os dias, só que agora não. Eu vou juntando, guardando. Já têm quantidade!”. Agora, vende para uma atravessadora, porque esta vem até sua casa, de caminhãozinho, buscar os bolsões de material coletado (lata, garrafa, plástico) e "nos outros tem que levar".

Há cinco anos, também trabalhou na colheita de maçãs, na cidade de Vacaria-RS, onde foi trabalhar para "aliviar a cabeça, e piorou. Entrei em depressão e comecei a cai pelo meio do pomar, aí eu vim embora”. O motivo do adoecimento foi o falecimento de dois filhos mais velhos, por envenenamento. Após este episódio, recebeu tratamento no Centro de Atendimento Psicossocial (CAPS), por dois anos. Sobre as dificuldades familiares, contou que atualmente dois outros filhos seus e o genro estão presos.

Entrou para a Associação a convite de seu genro e participa das reuniões do grupo, realizadas na universidade e diz que já se imagina trabalhando na associação, no galpão: Mas é assim, “(...) eu gosto de separar, de limpar, de arrumar, essas coisas assim de... reciclagem. (...) na rua pra mim nem dá, por causa que às vezes me incha esse joelho. Então, se eu ficar no galpão pra mim é melhor”. Perguntada sobre o cumprimento dos horários exigidos em um empreendimento, já que gosta da autonomia que a catação sempre lhe proporcionou, respondeu: "Sim, aí já é ter responsabilidade dos horários (...) e não tenho bebê pra não ir, pra chegar atrasada também. Não, a [filha] maior já tá com treze anos".

Contou que depois que entrou para a associação já viajou três vezes: Santa Maria -RS, Uruguaiana -RS e Porto Alegre -RS. "Nunca tinha saído e visto tanta coisa bonita!" E, sobre o trabalho realizado em mutirão, que serviu como experiência piloto para o trabalho coletivo, disse que foi bom, pois “todo mundo se uniu, entre nós seis, nós todos lá, a gente se dividiu, cada um fazia o seu serviço, deixava de fazer uma coisa pra ajudar o outro, ficava até mais tarde". Perguntei-lhe se sairia da associação caso lhe oferecessem um trabalho que considerasse melhor, e respondeu que se não gostasse de trabalhar na associação e se lhe pagassem mais, sairia.

Com relação aos sonhos de vida comenta que "antes tinha bastante, queria ter casa pra deixar pros meus filhos, pra dividir. Já tenho duas, então agora não tem mais sonho. (...) É come bem, agora, até porque já tão tudo criado, né?”. Inquirida se gostaria de voltar a estudar, respondeu que não, porque, aos 54 anos, acredita ser velha demais e, alem disso, como não gosta de coisas repetitivas, não voltaria: "me disseram que tinha que ver [repetir] $a, e, i, o, u$, diziam umas quantas vezes as coisas. Aí eu não tinha paciência”.

Muitas coisas eu aprendi ouvindo. A gente não sabia nem falar direito. E na reunião que teve, quando eu recebi o salário cidadão, aí que tinha os cursos de como ter diálogo com as pessoas, como conversar... antes eu não falava nada. (...). Eu fiz curso de madeira, de como 
saber se comportar na sociedade, de como falar com as pessoas, ouvir as pessoas, esperar que a pessoa se explique, pra depois falar, umas coisa assim.

As dificuldades da vida, entre elas a pobreza e o analfabetismo, levaram Olívia com seus filhos ainda pequenos, a trabalhar na catação, a fim de garantir o sustento. Hoje, apesar de entender que a vida melhorou, continua a praticar esta atividade, por ter se acostumado a ela, além de ver como uma forma de auxiliar a família. A autonomia em seus horários e a possibilidade de realizar viagens são alguns dos fatores que a fazem persistir na associação.

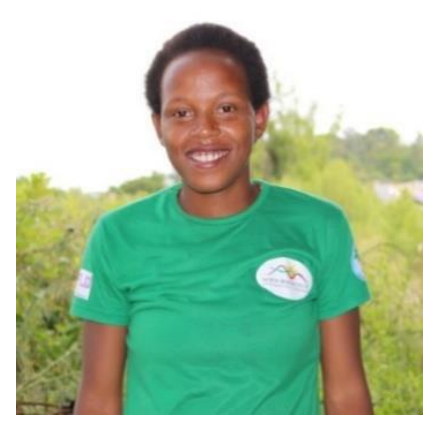

Figura 3. Patrícia Cristiane da Silveira Rodrigues. Fonte: Acervo Incubadora de ES Fronteira da Paz - UNIPAMPA.

\section{Patrícia Cristiane da Silveira Rodrigues}

"Saímos todos juntos trabalhar com a associação. Deu certo nesse tempinho. Foi Bom"

Patrícia, 27 anos, nasceu em Rio Grande- RS. Morou, por tempo em Rivera e agora vive em Livramento, no bairro Prado, com seus três filhos ${ }^{12}$, que ficam na escolinha durante o dia. Estudou até o $7^{\circ}$ ano e depois foi para a EJA, que não concluiu, devido ao nascimento dos filhos. Depois que os filhos crescerem, diz que pretende voltar a estudar. "Eu antes queria ser veterinária. Fazer curso pra fazer o cuidado, veterinária. E depois já desisti, né?”. Atua na catação desde criança, pois ela e os irmãos iam catar junto com a mãe.

A dificuldade que a gente teve mais era quando nós era pequeno mesmo. Quando a mãe chorava porque não tinha as coisas dentro de casa, pra dar pra gente. Foi aí que a gente começou a sair e ajudar ela. (...) a nossa dificuldade maior era ver a mãe chorar. Por causa de fralda, leite, né, pensar no que ela ia nos dar no outro dia. (...) depois que eu aprendi a me virar, até pras gurias ${ }^{13}$ não falta as coisas, não deixo faltar mais.

Pela manhã, ela e os irmãos, estudavam e, à tarde e à noite, catavam pelas ruas e depois chamavam a mãe para ajudar a carregar as bolsas. Desde os doze anos, ela conciliava os estudos, a catação, e os trabalhos de faxinas, em casa de família. Também morou em Vacaria/RS, por um ano e quatro meses, onde trabalhou na colheita e na poda da maçã. Retornou a Livramento quando sua mãe adoeceu, devido ao falecimento dos irmãos. Perguntei-lhe se estando na associação e fosse chamada para trabalhar na safra das maçãs em Vacaria-RS, se voltaria. Respondeu que não, pela penosidade do trabalho: "é mais difícil trabalhar lá, que na associação".

${ }^{12}$ Seu marido encontra-se preso.

${ }^{13}$ Referindo-se às filhas. 
Diz ter se acostumado ao trabalho da catação e hoje gosta de realizá-lo. Na atualidade, Patrícia coleta seus materiais próximo de sua casa, não indo mais ao centro da cidade, pois precisa cuidar das crianças e do sogro, que necessita tomar remédios em horários controlados. Os materiais que recolhe nas proximidades são comercializados junto com os juntados por sua mãe e são vendidos por mês, chegando a um montante de R 500,00 a $\mathrm{R} \$$ 600,00 , por venda. Sua renda é complementada pelo recebimento da Bolsa Família.

Sobre sua futura atuação na associação Patrícia, que é vice-tesoureira, diz que prefere trabalhar na rua pela possibilidade de caminhar, conversar e por não gostar de ficar trancada. Entende que todos trabalhando junto é melhor, porque assim precisam se organizar. Demonstra ter compreensão da necessidade de organização do grupo quanto ao cumprimento de horários e compromissos assumidos com as pessoas que lhe guardam materiais: "Se a pessoa pediu pra passar na sexta, lá pelas nove, independe se da manhã ou da noite, a gente tem que tá lá no horário”. Referindo-se ao mutirão realizado, comentou: “a gente já saiu, já trabalhou, saímos todos juntos trabalhar com a associação. Deu certo nesse tempinho. Foi Bom”. E sobre o trabalho futuro na associação, comenta:

O mais difícil vai ser, na hora eu acho de se organizar. (...) tem que ver quem vai pra rua, (...) quem mais vai seguir e quem vai entrar. A professora Cassi disse que vai ser mais pessoas: quem vai ser dentro do galpão, quem vai ser na rua, quem vai querer trabalhar nas máquinas (...). A maioria do nosso grupo quer na rua. (...) A gente já se conhece um pouquinho (...) e os outros a gente vai conhecendo de a pouquinho, dependendo de quem entrar na Associação.

Patrícia contou que, por estar na associação, viajou para Santa Maria-RS e Pelotas-RS, o que lhe pareceu bastante interessante, porque "a gente viu vários trabalhos com material reciclável, que muitas vezes, aqui, a gente não ia ver, mas lá pra fora a gente vê bastante”.

Em relação a ser mulher e catadora, Patrícia menciona:

Olha, no começo a gente se sente meia estranha, por causa que a gente sempre via mais homem. Mas depois até que a gente foi na palestra, lá em Porto Alegre, foi que a gente começou a se sentir mais importante. (...) a gente começou a gostar mais, ver que a gente também tinha um lugar, não era só os homens. Tem machismo, né, tem bastante machismo. (...) Tava trabalhando eu e as gurias de noite (...) eles passavam e corriam na nossa frente, aí eles iam de carroça e debochavam. (...). Porque a gente era um bando de mulher ali catando. (...) Mas, mais nessa parte quando a gente começou a trabalhar, que se tinha o machismo pro lado da gente. Mas com os guris do serviço não, por causa que já iam na reunião $14^{14}$, já viram que (...) tinha bastante homem, mas mais mulher, na frente, como nas palestra e tudo.

\footnotetext{
${ }^{14}$ Reuniões da associação realizadas pela incubadora fronteira da Paz.
} 
Sobre planos futuros, comenta:

\begin{abstract}
Mais pra frente eu quero voltar a estudar, mais por causa que agora também da associação, né. Como a gente tá como vice-tesoureira (...). Aí o professor [Altacir] falou até que vai dar umas aulas, vai dar uns cursos pra nós, aí todo mundo se interessou, porque a gente precisará. (...). É conta, é na escrita, são várias coisas. E como a gente vai assinar um papel, se a pessoa não entende, ou não entendem a letra da gente? Escrever uma ATA e não entenderem? Aí agora o professor vai fazer os cursos lá e tudo, pensando no depois. Aí dá pra trabalhar durante o dia e estudar durante a noite.
\end{abstract}

Patricia, que pelas dificuldades da vida não conseguiu realizar o sonho de ser veterinária, é uma mulher atuante na associação, percebendo a importância da participação em eventos sobre reciclagem e a necessidade de buscar constantemente o conhecimento para que o trabalho na associação efetivamente aconteça.

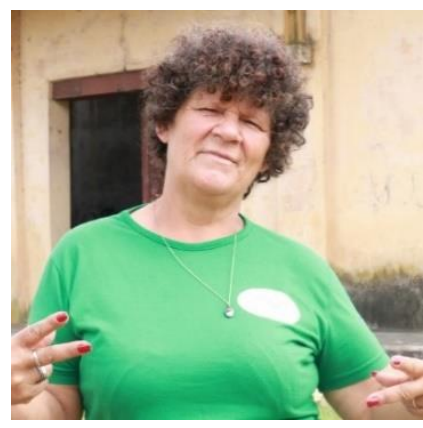

Figura 4. Carmem Maria Martins. Fonte: Acervo Incubadora de ES Fronteira da Paz. UNIPAMPA.

\section{Carmem Maria Martins}

"Vocês vão ter o prazer de me ver, Carmem Maria Martins Areas, representante da Cooperativa Novo Horizonte. Cheguei!"

Nascida em livramento, Carmem tem 60 anos e mora no bairro Parque das Águas. Mãe de seis filhos, viúva há quatro anos. Tempos atrás, perdeu metade de sua casa, devido a um incêndio iniciado na casa vizinha e recuperou tudo novamente, com ajuda alheia, mas também com seu trabalho na catação.

Quando jovem, trabalhou no Frigorífico Swift Armour, de onde saiu porque gostava de jogar futebol. Morou em Santa

Maria-RS, por dois anos, onde trabalhou como doméstica. Viveu também em Montevideo $^{15}$, por quatro anos, na casa de uma família que ela já havia morado anteriormente, em Manduví ${ }^{16}$.

Sua postura e seu modo de falar denotam uma autoestima elevada. Isto se comprovou quando ela relatou que sempre trabalhava bem arrumada: "eu sempre trabalhei de 'taco'. (...). Eu subia na carroça, chique, com as unhas bem pintadas, ninguém acreditava que eu era catadora, pelas unhas, entendeste?". Também se considera uma pessoa alegre, que gosta de ouvir música, tomar chimarrão, cerveja, jogar pontinho, ir a bailes.

Trabalha como catadora a cerca de 30 anos e, agora, enquanto aguarda a abertura da sede física da associação, diz que está parada, por não ter onde estocar as sucatas, que com

${ }^{15}$ É doble chapa. Este é um termo usado nas fronteiras do sul do país para distinguir o indivíduo que tem dupla nacionalidade. Disponível em: [Enlace] Acesso em 17 nov. 2018.

${ }^{16}$ Bairro de Rivera-Uruguai. 
o calor atrai mosquitos, mau cheiro, etc. Muitas pessoas, conhecidas suas, levam-lhe o material até sua casa, e ela estoca na casa de sua filha. Mas, comenta que se quisesse catar diariamente teria bastante material, pois "tem as farmácias, tem as lojas. Eu me dou com tanta gente, eu sou como "jujo (capim) brabo", dou em tudo que é lado, entendeu?! [risos]... onde eu chego já tão ali com material pra mim, entendeste?!" Como complementação da renda, recebe o benefício da Bolsa Família, por ter um filho estudando e também recebe ajuda monetária de seu filho que trabalha na campanha, como alambrador ${ }^{17}$. Não soube precisar exatamente quanto recebe mensalmente pelas sucatas, porém disse que dias atrás havia vendido um bag - bolsão grande - cheio de latas de cerveja, por R\$150.00.

Sobre a experiência de trabalho coletivo, como já mencionado nas entrevistas anteriores, Carmem conta que ao todo coletaram 36 bags de material, que ela levou tudo anotado, inclusive cobrou das outras companheiras esse controle. Estas diziam não anotar, pois quem anotava era um colega. Em suas contas, faltou um bag, o que ele negou. "Aí eu digo: 'não! Se é pra tá na rua trabalhando e tu não ver o resultado ${ }^{18}$, não vale a pena'. Entonces, eu parei. Pra mim não me serve essa palhaçada!”.

Sua entrada para a associação é vista por ela como uma causa que abraçou "Porque é uma coisa que eu sei que dá (...) Se a pessoa tiver força de vontade, (...) tu pega mais dinheiro (...) mais que qualquer outra que trabalha aí por mês. (...) Quando viajo, olho como trabalham, se organizam. Como eu disse pra Tugira: 'o sol ainda não brilhou pra mim, porque eu já sou o brilho [risos], mas o dia que ele brilhar, ninguém me parar, mana! (...)!

Com relação ao trabalho na coleta seletiva, como futura possibilidade de vir a ser assumida pelos catadores da associação, Carmem a compara a uma pessoa que aprendeu a andar de bicicleta, pois esta jamais vai esquecer: "Se tu aprendeu uma coisa, tu não vai te esquecer jamais. Pra mim, a coleta é a mesma coisa. Se eu sempre fui isso. Pra mim, isso aí é normal, entendeste?”. Sobre o fato de ser um passo maior do que estão acostumados, perguntei-lhe no intuito de saber se isto lhe assustava, ao que ela respondeu: "Ao contrário, acho até melhor. Porque agora é que tão com o queijo e a faca na mão, se não aproveitarem (...)". Provocada a perceber que o compromisso com a coleta seletiva envolve mais que tempo de estar na rua, mas também a participação em reuniões, cumprimento de horários, entre outros, atalhou: "Sim, mas se você combinou de entrar naquilo ali, você já tá sabendo o que vai passar pela frente. Por isso que eu digo a pessoa tem que tá preparada psicologicamente também, né. Entonces, é como eu digo, se a pessoa não quer, tenho que botar pra rua”. Em outro momento, a tesoureira da associação já havia comentado: "uma andorinha só, não faz verão".

\footnotetext{
${ }^{17}$ Que faz cercas de arame farpado, nos campos.

${ }^{18}$ Carmem comentou que trabalharam uma semana inteira para receberem apenas $\mathrm{R} \$ 60,00$, por pessoa. E esse valor ela diz não ter aceitado, deixando para suas colegas.
} 
Para o seu futuro e o do grupo, declarou: "Bah eu me vejo no auge. Porque não vai ser só a Tugira ${ }^{19}$. Já disse que eu vou fazer um livro da minha vida". Carmem diz que pretende literalmente fazer um livro de sua vida: "e vou fazer... tenho capacidade pra fazer". Contou que gosta de escrever versos: “(...) eu adoro escrever. (...) as pessoas não dão nada pela gente, né?! Mas eu não preciso também que as pessoas me deem nada. Eu sabendo do que eu sou capaz, é o que me interessa. Opinião dos outros, tô me lixando, entendeu?” E complementa: "eu não tô dizendo pra vocês que eu me vejo no auge. Vocês vão ter o prazer de me ver, Carmem Maria Martins Areas ${ }^{20}$, representante da Cooperativa Novo Horizonte. Cheguei”. Diz que mesmo que lhe oferecessem outro trabalho, em outro lugar ela não aceitaria, pois gosta de trabalhar "livre, leve e solta. Ninguém me molesta, eu sou a patroa!".

Carmem é uma mulher que contagia as pessoas pelo seu bom humor e autoestima. É bastante brincalhona, porém, demonstra levar a sério sua entrada para a associação, que ela vê como uma causa que abraçou. É exigente com seus colegas, no que diz respeito ao cumprimento das regras estabelecidas. Percebe as viagens e eventos que participa como uma oportunidade de aprendizagem sobre o trabalho na associação e gosta de imaginar que o futuro exitoso desta lhe trará notoriedade.

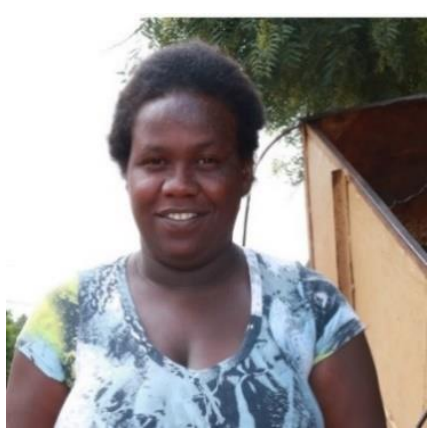

Figura 5. Lidiane da Silveira Rodrigues. Fonte: Acervo Incubadora de ES Fronteira da Paz. UNIPAMPA.

\section{Lidiane da Silveira Rodrigues}

"Primeiro eu tenho que tá lá pra depois te dizer. Eu não tenho imaginado nada, eu vivo o dia a dia, eu vivo o presente" (Sobre o futuro da associação).

Lidiane nasceu em Rio Grande- RS, mas veio ainda pequena, morar em Santana do Livramento. Casada com $\mathrm{Au}-$ gusto, também catador, recém-associado na Novo Horizonte, ela é mãe de três filhos. Ainda bebê, foi morar coma família em Rivera-UY e, aos oito anos, retornou a Santana. Conta que ao mudar-se da vizinha cidade uruguaia para a brasileira teve uma surpresa, pois foi a primeira vez que viu "um bico de luz ${ }^{21}$ ". "Lá, não tinham luz elétrica, somente à

bateria. Também não tinham água encanada, necessitavam buscá-la de balde. Foi difícil a mudança de cidade por deixarem lá suas amizades, vizinhos”, comenta. Entretanto, a decisão de se mudarem ocorreu em função de um tiroteio que houve nas redondezas, que deixou sua mãe assustada: “(...) no dia do tiroteio nos corria no meio das balas, então ela ficou brava, ela disse que ia se mudar e se mudou mesmo (...)”.

\footnotetext{
${ }^{19}$ Catadora Maria Tugira Cardoso, da Associação ACLAN, de Uruguaiana. Em setembro de 2018 recebeu o troféu Kikito de Melhor Atriz, no festival de Cinema, em Gramado-RS, com o documentário Catadora de Gente.

${ }^{20}$ Em sua carteira de Identidade consta apenas como Carmem Maria Martins.

${ }^{21}$ Lâmpada.
} 
As dificuldades vividas pela família a levaram, junto dos irmãos, desde quando moravam em Rivera, a colaborarem com a renda da família: de manhã, iam à escola, à tarde, ela e alguns irmãos vendiam pares de meias ${ }^{22} \mathrm{e}$, à noite, saiam para catar. E, nesse sentido, afirma que foi assim que começou a sua vida como catadora. Do dinheiro arrecadado com a venda das meias, entregavam $\mathrm{R} \$ 15,00$ ao fornecedor e o restante entregavam a sua mãe, para comprar leite, pagar luz e água. Quando cresceram um pouco mais, sua mãe fazia pastel, bolinhos e pães que ela e os irmãos vendiam nas casas. Assim, contou Lidiane, foram juntando dinheiro e sua mãe pode comprar a sua primeira casa.

Quando já moravam em Livramento, uma assistente social encontrou-os na rua e conhecendo as dificuldades da família, inscreveu sua mãe para receber o salário cidadão. Este dinheiro melhorou um pouco a situação da família, possibilitando que sua mãe não precisasse mais trabalhar com faxinas. Porém, como ela não conhecia dinheiro, Lidiane, com a ajuda de uma tia e do irmão, administrava-o, inclusive intermediou a compra da casa.

Frequentou a escola até o sexto ano, quando fugiu e abandonou os estudos, para ir trabalhar em Vacaria- RS, na colheita das maçãs, a fim de ganhar dinheiro, pois queria comprar roupas. Ficou lá por 45 dias, mas, ao voltar, percebendo que já havia perdido o ano letivo e tomando gosto pelo dinheiro, decidiu que queria continuar trabalhando. Sua mãe a obrigou a estudar, à noite, porém Lidiane contou que esse foi o erro, pois à noite era mais fácil "matar aula". Percebendo isso, sua mãe concordou que fosse trabalhar na casa de uma professora, como acompanhante: "eu era companheira, eu era a "luluzinha" dela, aonde ela ia eu ia com ela (...)eu ajudava ela a limpar a casa, bem dizer eu era uma companheira”. Depois desse trabalho, retornou mais algumas vezes a Vacaria - RS, porque lá conseguia mais dinheiro.

Contou ter conhecimento da associação pela sua mãe, que lhe pediu que se inscrevesse. Ela diz que inicialmente não teve interesse, pois não queria dividir o dinheiro com outras pessoas. Acreditava que trabalhando sozinha ganharia mais. Sua mãe explicou que cada um teria seu caderno para anotar o quanto coletou e quanto vendeu. Agora, diz estar compreendendo como funciona uma associação, porque logo que entrou foi numa viagem a Porto Alegre -RS, onde lhe ensinaram como começaram as associações e como funcionavam os projetos para catadores. Sobre isso comenta: "eu gostei porque eu aprendi bastante coisa, porque tinha muitos até, antes da associação, que tavam até passando fome, depois entraram para associação e dão a volta por cima”. Atualmente, Lidiane é a vice-presidente da associação e diz gostar de fazer parte e que fica triste por ver que muitas pessoas desistiram. Porém, acredita que quando tiverem equipamentos e o galpão muitos voltarão. Quando iniciar o funcionamento do empreendimento, diz que prefere trabalhar na rua, pois já se acostumou. Perguntei-lhe como vê o futuro da associação e ela respondeu: "primeiro eu tenho que tá lá pra depois te dizer. (...) eu não tenho imaginado nada, eu vivo o dia a dia, eu vivo o presente". Sobre ter sonhos diz: "eu gosto do dinheiro pra pagar minhas

${ }^{22} \mathrm{O}$ outro irmão era cuidador de carros, no centro da cidade. 
contas (...), a boia e (...) um tetinho, pra mim e pros meus filho (...) eu não tenho tanta ambição".

O que ela e o marido catam é armazenado no pátio da casa, que é pequeno, e, por isso, coletam pouca coisa, sendo necessário que o marido trabalhe em outras atividades cortar lenha, podar árvores - para complementar a renda.

Lidiane desde pequena conciliava os estudos com o trabalho na venda de pares de meias e de alimentos, preparados por sua mãe, com a catação. Acostumada à lida de trabalho, com rotina, acredita que com a implementação do galpão e equipamentos, a associação irá funcionar.

\section{CONCLUSÕES}

Este estudo buscou conhecer as histórias de mulheres catadoras de materiais recicláveis que participam da Associação de Catadores Novo Horizonte. Direcionamos o olhar às dificuldades enfrentadas, aos sonhos e à ausência de sonhos, à forma como se veem e se organizam, bem como às perspectivas que têm para o futuro na associação.

Desprende-se disso tudo que as dificuldades enfrentadas por elas convergem, pois todas provêm de contextos pobres e que sofreram exclusão, obrigando-as, desde cedo, a migrarem para a catação para manter a sobrevivência. Outra constatação é a de que se acostumaram a este trabalho e que dizem gostar, principalmente, pela autonomia que gozam de fazerem seus próprios horários, pela liberdade de andarem pelas ruas e se organizarem no seu tempo e no seu espaço. Suas falas denotam que há um conhecimento acerca da catação que lhes dá segurança, no que tange a realização do trabalho na associação, principalmente, o que continuará sendo realizado nas ruas, pois, para elas, as suas rotinas não serão modificadas. Os cursos que participaram e as visitas realizadas a outros empreendimentos, também lhes possibilitou novos conhecimentos, literalmente, novos horizontes. O cumprimento de horários, a participação nas reuniões parece ser o maior desafio, no entender delas. Os seus sonhos, para dentro e fora da associação, transitam entre o atendimento das necessidades materiais, básicas, da família e a busca por notoriedade, como brincou a catadora Carmem, quando disse que se vê no auge, inclusive almejando um livro escrito sobre sua vida.

Quanto aos planos futuros para a associação, percebe-se que para a maioria é difícil traçá-los, diante da inexistência de algo concreto - galpão e equipamentos - e pelo fato de que nunca trabalharam em um galpão. Percebeu-se, nas entrevistas, que elas depositam muita confiança e segurança na assessoria recebida pela incubadora, em especial na pessoa do Professor Altacir Bunde, atual coordenador. Nesse sentido, nota-se um encorajamento por parte delas, pois precisam de referências fortes, de modelos de como fazer as coisas, uma vez que não tiveram essas práticas incorporadas em seu cotidiano. Deste modo, a 
assessoria para a organização do empreendimento (sua legalização, controle de pagamentos de despesas, planilhas, organização de reuniões - local, horário - etc.), ao passo que lhes auxilia, também é educativa, pois vão paulatinamente percebendo a necessidade de organização, da importância de adquirirem novos conhecimentos. Nesse ponto, faz-se necessário ir delegando-lhes funções, mesmo que inicialmente tenham dificuldades. A educação popular entende que é necessário criar a contradição no sujeito (desacomodá-lo) para que haja a mudança, a emergência de autonomia.

A incubadora Fronteira da Paz, por atuar na perspectiva da educação popular e da economia solidária, trabalha com metodologias participativas, envolvendo os catadores na execução das atividades. Dentre as formações realizadas estão a constituição de um Plano de Ações, Oficinas de capacitação para autogestão (reforma e alteração do estatuto), de Marketing Digital, Seminários com catadores de outras associações para troca de experiências, mutirões de limpeza, em que foram convocados a trabalharem em eventos acadêmicos, shows municipais e na experiência coletiva de coleta nas ruas do centro da cidade e em bairros adjacentes.

Somadas às formações técnicas, que vem acontecendo, é que compreendemos a importância das histórias de vida apresentadas neste artigo. Utilizadas como estratégia de formação, de conhecimento e de aprendizagens, essas contribuem para a afirmação das vivências das mulheres pesquisadas e, por conseguinte, estendem-se aos demais membros da associação. Ao se ouvirem, perceberam-se como sujeitos sociais, capazes de experienciar novos caminhos, como, por exemplo, o associativismo. Passam a valorizar suas trajetórias, percebendo, por exemplo, como afirmou a catadora Sara, que ser mulher catadora é olhar o que vem pela frente, é ser uma guerreira, que não se abaixa por pouca coisa. É dessa forma que viemos até aqui compreendendo a emergência de uma emancipação social das catadoras da Associação Novo Horizonte.

Entretanto, ao chegarmos final deste estudo, caiu-nos em mãos o artigo intitulado Cruzando os caminhos da economia solidária e do feminismo: passos para uma convergência necessária, de Hillenkamp; Guérin; Verschuur (2017). Para estas autoras a economia solidária tem, em certa medida, negligenciado as questões de gênero e do feminismo. Dessa forma, levantam as seguintes questões: "poderiam as mulheres encontrarem na economia solidária um caminho para a emancipação? Ou seria a solidariedade entre mulheres, muitas vezes subalternas, reprodutora de mecanismos da sua própria exploração?” (Ibid., p. 43-44). Mas este é assunto para uma próxima reflexão.

\section{REFERÊNCIAS}

AMADO, João; FERREIRA, Sónia. Estudos (auto)biográficos - Histórias de Vida. In: AMADO, João; FERREIRA, Sónia (Coord.). Manual de Investigação Qualitativa em Educação. 2 ed. Coimbra: Imprensa da Universidade de Coimbra, 2014. P. 169-186. 
BAUMAN, Zygmunt. Vidas desperdiçadas. Tradução de Carlos Alberto Medeiros. Rio de Janeiro: Jorge Zahar Ed, 2005.

BECKER, Howard. Métodos de pesquisa em ciências sociais. Tradução de Marco Estevão, Renato Aguiar. 4. ed. São Paulo: Hucitec, 1999.

FREIRE, Paulo. Pedagogia da autonomia: saberes necessários à prática educativa. São Paulo: Paz e Terra, 2002.

—. Pedagogia do oprimido. 50 ed. Rio de Janeiro: Paz e Terra, 2011.

HILLENKAMP, Isabelle; GUÉRIN Isabelle; VERSCHUUR Christine. Cruzando os caminhos da economia solidária e do feminismo: passos para uma convergência necessária. REVISTA ECONOMÍA, Quito-Equador, v. 69, n. 109, p. 43-60, mai. 2017. Disponível em: [Enlace] Acesso em: 02 dez. 2018.

JOSSO, Marie-Christine. Experiências de vida e formação. Prefácio de António Nóvoa; tradução José Claudino e Julia Ferreira; adaptação à edição brasileira Maria Viana. São Paulo: Cortez, 2004.

SCARIOT, Nadia. A socialização profissional de catadores de materiais recicláveis e a constituição de saberes profissionais e emancipatórios. 2016. 205 f. Tese (doutorado) Universidade Regional do Noroeste do Estado do Rio Grande do Sul (Campus Ijuí e Santa Rosa). Educação nas Ciências, 2016.

SINGER, Paul. A recente ressurreição da economia solidária no Brasil. In: SOUSA SANTOS, Boaventura de (Org.). Produzir para viver: os caminhos da produção não capitalista. Rio de Janeiro: Civilização Brasileira, 2002. v.2. p. 81-129.

SOUSA SANTOS, Boaventura de. A crítica da razão indolente: contra o desperdício da experiência. São Paulo: Cortez, 2000 Vol. 1.

—. Renovar a teoria crítica e reinventar a emancipação social. São Paulo: Boitempo, 2007.

—. NUNES, J. A. Introdução: para ampliar o cânone do reconhecimento, da diferença e da igualdade. In: SOUSA SANTOS, Boaventura. (org.). Conhecer para libertar: os caminhos do cosmopolitismo multicultural. Porto: Edições Afrontamento, 2004, p. 20-51.

—. Um discurso sobre as ciências. 4 ed. São Paulo: Cortez, 2006.

\section{Outras Fontes:}

BARRIOS SOAREZ, Sara. História de Vida. 03 set. 2018. Entrevista concedida a Nadia Scariot, Cassiane da Costa e Edenilson Tafernaberry.

MARTINS, Carmem Maria. História de Vida. 05 set. 2018. Entrevista concedida a Nadia Scariot, Cassiane da Costa. 
RODRIGUES, Lidiane da Silveira. História de Vida. 02 out. 2018. Entrevista concedida a Nadia Scariot e Edenilson Tafernaberry.

RODRIGUES, Patrícia Cristiane da Silveira. História de Vida. 26 set. 2018. Entrevista concedida a Nadia Scariot e Edenilson Tafernaberry.

SILVEIRA, Lígia Mara Lima de. História de Vida. 26 set. 2018. Entrevista concedida a Nadia Scariot e Edenilson Tafernaberry. 